\title{
POSSIBLE SIGHTING OF GLOSSY IBIS IN SASKATCHEWAN
}

ROBERT KREBA, Saskatchewan Museum of Natural History, Wascana Park, Regina, Saskatchewan. S4P 3V7

On 14 August 1979, Fred Lahrman received a call from Dave Duffus (Ducks Unlimited), who reported that a dark ibis had been spotted by a DU staff member near Courval, on the west end of Old Wives Lake. The next day we drove out to the area, but could not find the bird, which we assumed to be a White-faced Ibis (Plegadis chihi).

White-faced Ibis had first been reported, and confirmed in Saskatchewan in 1976. ${ }^{410}$ Until 1979, there had been several other sightings in the province. ${ }^{3 a}$ The very similar Glossy lbis (Plegadis falcinellus) had not been previously reported from the prairie provinces to my knowledge.

On 16 August, I talked to Phil Browne, who had observed the ibis, and also was able to read his detailed, on the spot field notes. The ibis was carefully observed for about 30 minutes, in good light, with $10 \times 50$ binoculars and $45 x$ spotting scope, at distances of 20-50 yards. Two photos taken at the time clearly show that it was a Plegadis species, but the diagnostic markings, described below, are not apparent.

At the same time, Browne showed me the exact location on a topographic map of the area. The slough where the ibis was seen was on a prairie "trail", on the east side of a grid road running northsouth through the site of the former village of Eastleigh. By measurement of the map, it was $11 \mathrm{~km} \mathrm{N.E.} \mathrm{of} \mathrm{Courval}$ and $7 \frac{1}{2} \mathrm{~km} \mathrm{S.S.E.} \mathrm{of} \mathrm{Eastleigh.}$

It was clear that, with the little information we had, Lahrman and I had been looking in the wrong place. As
Browne's notes indicated the possibility that the ibis was not a White-faced, we decided to try again, and hopefully get documentative photos. On the 17 th, we set out again and searched the area but without seeing the bird. The ibis could have been at any one of hundreds of sloughs in the area, or could have been at Old Wives Lake to the south, or Chaplin Lake to the west. In any case, it was not seen again.

The ibis, as described in Browne's notes, is clearly an adult bird showing the typical chestnut plumage, with metallic greenish and purplish gloss. A few light feathers on the throat and above the eye indicate that it was just starting to move into basic, or winter, plumage.

The notes reveal that the eye was completely dark (brown with black pupil), showing no red colouration. The legs were dark, also showing no reddish. The colour of facial skin was not noted, but when I asked him about it, Browne recalled it as being dull or greyish, again with no evidence of red. There was no trace of the border of white feathers surrounding the eye and bare facial skin seen in the alternate, or breeding, plumage of the White-faced Ibis.

The two species of ibis, regarded by some authorities as conspecific, ${ }^{56}$ are notoriously difficult to separate, especially outside of the breeding season. The diagnostic markings are best summarized in an article by $H$. Douglas Pratt, in Birding magazine, ${ }^{7}$ as follows. The bird observed by Browne agrees with $P$. falcinellus in: 1) brown, not red, 
iris; 2) dark legs with no trace of carmine; 3 ) greyish, not carmine or reddish facial skin, and 4) no trace of white feathering bordering the bare facial skin.

Again following Pratt, ${ }^{7}$ these diagnostic features could be refuted thusly: 1) some winter White-faced Ibis may have brown irises, and under poor light conditions, carmine irises may appear brown (although in this case viewing conditions were good); 2) outside of breeding season, legs of both species appear olive-grey, and Glossy shows carmine at ankle joint in full breeding dress, which was not noted (but which would be hard to see in the field); 3) the bright carmine facial skin of breeding condition White-faced Ibis is "less intense" after breeding, and fades to "dark smoke-grey in the winter. As well, facial skin of Glossy Ibis is described as being two-toned: "plumbeous ... margined above and below with pale sky-blue." This two-toned effect was not observed, but again this fades after oreeding; 4) the white facial feathers of White-faced Ibis may have already been ost, although at least some trace of hem should have been present at this date.

I reviewed the records in American Birds for the last ten years (vols. 25 hrough 35) for records of the Glossy bis to the north and west of its usual ange. The areas surveyed were: Western Great Lakes Region, Middlevestern Prairie Region, South Texas Region, Southern Great Plains Region, Northern Great Plains Region, and Prairie Provinces Region (split from Northern Great Plains commencing vol. 3).

Predictably, the most numerous eports, 15 sightings of 24 birds, were rom the Middle-western Prairie Region, he most south-easterly of the regions urveyed. The Western Great Lakes legion had 4 sightings of 7 Glossy Ibis, sightings in Wisconsin and 1 in Michigan. Both regions reported larger umbers of White-faced and Plegadis $\mathrm{sp}$. ibises, but the number of Glossy Ibis sightings was higher than I expected.

There was a different pattern of seasonal distribution between the two regions. In the Middle-western Prairie Region, the great majority of Glossy lbis were seen up to the end of May, only 2 birds in 2 sightings in June-July, and 3 birds in 2 sightings in fall. In the Western Great Lakes Region to the north, there were no spring sightings, 1 bird in JuneJuly, and all the rest in the fall. This might suggest that these more northerly records were the result of post-breeding dispersal.

Only White-faced Ibises were reported from the Southern Great Plains Regions, which lies west of the Mississippi River and includes Nebraska, Kansas, Oklahoma, and Texas excluding the extreme south and Gulf coast. This area, the South Texas Region, had one sighting of a single Glossy Ibis, in April, at Galveston on the Gulf coast.

For the Northern Great Plains and Prairie Provinces Regions, there is a single record of 3 Glossy Ibis, in late August, near Sioux Falls, South Dakota, which is in the southeastern part of that state. ${ }^{2}$ The only other possible record is of an unidentified Plegadis sp. ibis seen "about May 18" near Langruth, Manitoba, in 1972. ${ }^{3}$

Three years later, again in May, White-faced Ibises were definitely identified "for the first known sight records in Manitoba" at Lake Winnipeg and Oak Hammock Marsh. ${ }^{8}$ As noted earlier, Saskatchewan had its first sightings the following year, 1976, one of which was photographed to confirm the species for the provincial list. ${ }^{4} 10$ While Saskatchewan had several subsequent sightings, there have been no more in Manitoba.

In Alberta, White-faced Ibis was first sighted in June, 1974, at Pakowki Lake, in the south-eastern part of the province. ${ }^{13}$ They have been seen there 
at least two other years, 1975 and 1979 , and there is some indication of breeding in $1975 .{ }^{13}$ There are also sightings, "1 pair and 2 singles" at Stirling Lake near Lethbridge in $1975 .^{9}$

In North Dakota, South Dakota, and Montana, White-faced Ibises are seen more regularly and in larger numbers. Breeding has been confirmed in North Dakota, ${ }^{11} 12$ and South Dakota, ${ }^{12}$ and is suspected in Montana. ${ }^{9} 12$

The main problem with the positive identification of the ibis in question is that it was not in full breeding plumage, as indicated by the few white feathers on the throat and above the eye. While soft part colours such as legs and facial skin fade relatively quickly, the ibis, if Whitefaced, would seem to have developed extremes of full-winter "plumage" in the soft parts while barely beginning to change in feathering. In particular, it seems odd that there would be no trace of the white facial border feathers, while the rest of the plumage was nearly intact in the alternate.

Finally, I would note that American observers in the regions surveyed (see above), who are more familiar with both species, felt competent enough to identify Glossy Ibises, as distinct from Whitefaced, after the breeding season to as late as September 26, the extreme late date recorded. ${ }^{14}$ It would seem that the suspected Saskatchewan bird, at the relatively early date of August 14, should still be specifically identifiable under ideal conditions.

While not previously published, this record seems to warrant inclusion in the list of hypothetical species reported for Saskatchewan. In particular, the detailed field notes by Phil Browne may be the strongest argument for its inclusion. Without these, there would have been no case for suggesting that the ibis was a Glossy, rather than the more likely White-faced. I should note that the identification proposed is my own, and not the observer's, and that if in error, that error is also mine. Finally, I would be pleased to hear from any observers who are more familiar with the sequence of post-breeding soft part and plumage changes in both species of Plegadis ibises.

'GOLLOP, J.B. 1979. Prairie Provinces Region. American Birds 33:872-874.

${ }^{2}$ HOUSTON, C.S. 1972. Northern Great Plains Region. American Birds 26:78-80.

${ }^{3}$ HOUSTON, C.S. 1972. Northern Great Plains Region. American Birds 26:869872.

${ }^{3 a}$ HOUSTON, C.S., M.I. Houston and J.B. Gollop. 1981. Additions to the Check-list of Saskatchewan Birds since 1969. Blue Jay 39(3): 145-154.

${ }^{4}$ LAHRMAN, F.W. 1976. White-faced Ibis in Saskatchewan. Blue Jay 34:238.

${ }^{5}$ PALMER, R.S. (Ed.). 1962. Handbook of North American Birds, Vol. 1, (Loons through Flamingos). Yale University Press, New Haven and London.

${ }^{6}$ PARKES, K.C. 1961. Systematic Notes on North American Birds. 1. The Herons and Ibises (Ciconiiformes). Annals of the Carnegie Museum 33:287-293.

'PRATT, H.D. 1976. Field Identification of White-faced and Glossy Ibises. Birding 8:1-5.

${ }^{8}$ SERR, E.M. 1975. Northern Great Plains Region. American Birds 29:867-870.

${ }^{9}$ SERR, E.M. 1975. Northern Great Plains Region. American Birds 29:995-999.

${ }^{10}$ SERR, E.M. 1976. Northern Great Plains Region. American Birds 30:969-972.

${ }^{11}$ SERR, E.M. 1978. Northern Great Plains Region. American Birds 32:1175-1178.

${ }^{12}$ SERR, E.M. 1979. Northern Great Plains Region. American Birds 33:874-875.

${ }^{13}$ SMITH, W.W., and C.A. WALLIS. 1976. Preliminary Investigation of the Birds of Pakowki Lake. Blue Jay 34:168-171.

${ }^{14}$ TESSEN, D.D. 1977. Western Great Lakes Region. American Birds 31:179-182. 